\author{
Crossing the Border: International Journal of Interdisciplinary Studies \\ Volume 5; Number 2; 15 July 2017 \\ ISSN 2350-8752 (Print); ISSN 2350-8922 (Online)
}

\title{
FROM MARGIN TO CENTRE: A STUDY OF ENNOBLEMENT IN SHOBHA DE'S SOCIALITE EVENINGS
}

\author{
Dr. T.S. Ramesh (India) \\ R. Vanitha (India)
}

\begin{abstract}
The protagonists of Shobha De do not want to be docile, weak and dependant women. They want to be powerful and ready to revolt against unfair treatment and are not for compromise. They always want to show self-confidence in abundance. Boldly, they are ready to challenge hinders so that they attain their desired goal. They tend to be aggressive always, which helps them to shatter the male ego and male hierarchy. In order to be precise, they are not doormats. They raise their voice strong against patriarchal culture and marginalization of women. Thus, this paper aims to prove that how women in India tend to be transformed from margin to centre. It also aims to prove the fact that they want to be liberated physically and mentally and long for an independent identity by being aware of the choices open to them.
\end{abstract}

KEYWORDS: Marginalization, patriarchy, women's liberation, relationship

In her novels, Shobha De has brought out intimate understanding of the psyche of women and their problems. Her treatment of the contemporary urban women's position and challenges they face are not without significance. In an interview with Nayar, she said, "I did write with a great deal of empathy toward women. Without waving the feminist flag, I feel very strongly about the woman's situation" (as cited in Mahajan, n.d., p 12). From this expression, we come to know that she is unique in her writing.

Indian fiction depicts three kinds of women: first, the poor, women, belonging mostly to the rural class as portrayed by writers like Kamala Markandaya and R.K. Narayan; secondly, the middle class women, especially the educated and employed as depicted by writers like Nayantara Sahgal and Shashi Deshpande; and thirdly, the neo-rich aristocrat women as depicted by writers like Namita Gokhale and Shobha De. In the sense, De's characters come from the upper class Indian society.

De has treated women's issues in her works. She focuses on the cause of Indian women as R.S. Pathak observes that her works seem to be the modern version of picaresque novels of the eighteenth century. The picaro in this case is a woman but she, too, is avid of experiences, in search of which she goes from place to place. Pathak further asserts, "One may not like everything in De's fiction, but her treatment of the contemporary urban women's challenges, predicaments, and values and life style is surely not without significance" (p. 36). Her novels reflect a variety of shades of woman's mind and their plight in the Indian society. They try to shatter patriarchal hegemony and give a new approach to her protagonists. So, her protagonists have become unique. In India, women are not treated the same as their male counterparts. To women in India, freedom is out of the question. In 


\section{Crossing the Border: International Journal of Interdisciplinary Studies}

order to strip off their abject status, they raise their voice against lignifications of women. When women long for true love, women in the patriarchal society tend to be gutty. Keeping this in her mind, De's Karuna in Socialite Evenings is against other women. She is a selfconscious modern woman. As a young lady, she wants "to explore her own world" (p. 6), and "She always wants to be different" (p. 9). Even from her childhood, she has "hunger to be great and it grows greater by the day" (p. 9). She is preoccupied herself with the events that take place around her. She tries to scan those events around her and this helps her psyche to discover more on the mundane world. She is considered to be intransigent even by her father, mother, and her sisters. As an individual, Karuna prefers "to remain the wideeyed fan, and mute admirer" (p. 26) to the outside world. She expects others to treat her as equal in their relationship with her. She wants to push humiliation out of her mind in spite of "the pulls and strains it inevitably sets up" (p. 35).

Karuna wants to be frank. She has the will and this is absorbed by De in the following lines: "On my own, free of family influences and pressures, free of Anjali, prepared to discover the world" (p. 53). She longs for 'exhilarating moment' hoping that this would help her to find out about herself. For this, She wants to be "a big brave girl" (p. 57). When she wants to be assertive, she "resents superficial questions" (p. 59). She needs a space. In it, she wants to explore more about herself. This is expressed by her in the following lines, "I need my own space. I need to find myself" (p. 59).

Karuna wants to tell everything outright and not for dissimilation. As a young lady, she wants to make her life entirely different. She is a believer of karma or fate. She feels a potent force and knows pretty well that it rules her life. At the same time, she does not succumb to this and could spend her life "swooning over flowers and gorging on chocolates" (p. 57). She feels her new fangled ideas that may do her good. In other words, she tries to inculcate a motto in which, she says, "you're doing OK. You've got a place of your own" (p. 62).

Though Karuna has a new approach to life, she wishes to approach it with seriousness. This is seen with her half-amused, half-irritated tendencies along with her liking for headon, dead-on approach. She has "no desire to exacerbate, thing" (p. 66). She looks at life in its fabulous nature. This makes her terribly soignee and sophisticated. She tries to create "a liberated woman fantasy persona" (p. 72) for herself. For this, Gloria Steinem and Germaine Greer have helped her too much. Their works may be a sort of help to control her life. She sees, in Bombay, that a lot of scenes around her, in which, "women worked, women married, women divorced, and women remained single..." (p. 72). It is such a big deal and this helps her to come out of her coward or how to overcome the failure in her life.

To Karuna, life is a special thrill. In it, she wants to immerse herself fully. In fact, she does not want to share this with men, even either to her father or to her husband. Moreover, she does not allow her private world to be accessed by anybody, especially men and wants "to inhabit different planets" (p. 76). She does not allow herself to be reduced to the level of marginal. In fact, she wants to cruise around the world to know more about life. She longs to go to places like Morocco, Tangier and China and hopes that this kind of exploration may help her to come out of triviality. Her priorities are foremost and primary things to her. She does not allow others to consider her needs as secondary to them. All her sordid and messy story is transpired with her as commonly as she could. As a result, she is relieved by her reaction.

Karuna does not want to sit under a roof over her heads or "happy to have a four square meals a day" (p. 77). She does not allow anyone to taunt, humiliate or demoralise her. She knows pretty well that her life is a battleground and is ready to work not like a dependent doll. 


\section{FROM MARGIN TO CENTRE}

She does not like to see men as heroes and saviours, including her husband. In fact, she wants to work out a formula which can ensure peace and bliss to her. She hears a voice within her, when she sees of senses domestic trappings. It tells, "you look as if you are about to implode" (p. 78). At such point, she wants to behave like a mature and intelligent person.

Karuna works very hard to attain resonance in her life, through the writers of the past, who have helped her too much. Writers like "Yeats, Kurosawa, Yevteshenko and Maria Callas" (p. 80 ) have helped her to discover more about life with their ideas and words. Their works also help her to have, "all sorts of exciting new dimension" (p. 80). She always aims at organic growth. She feels that in her development Jung, Freud and Camus have helped her to attain this to some extent. She says, "They remain here, in their works, that her life is not a total write-off. In fact, they help Karuna, to stop pretending that everything was fine - to myself at any rate" (p. 95). Karuna always wants to be different. She does not want to be insensitive to certain situations. She wants to make others see her nature which tends to be not only crazy but also animated with defiance.

Karuna comes across little ugly episodes in her family life. Sometimes, these little episodes may hurt and humiliate her. Still, she works hard to solve it. She wants to be transparent in her life. She does not wish to wear the mask. Even if she forces to have this, she works in such a way that "the mask is perfect. It's just that I recognized it instantly since I wear an identical one myself" (p. 99). She always behaves like a clever lady. She is ready to express her feelings to her husband without hesitation. The following words of her clearly show this:

You really make me sick. I think our marriage was over the day our awful honeymoon started. We've got nothing going. I don't love you - never have. As for you - I really don't know to this day why you chose to marry me. I don't think you even know who you married. You don't have a clue what sort of a woman I am. I'm tired of your smugness, your irritating mannerisms, the way you take me for granted and expect me to fall into your overall scheme of things. I really don't care one way or the other if I ever see you again. So just get off my back. (p. 227)

Some readers may think that it is an emotional outburst. When Karuna is succumbed to emotional outburst, and she avoids it swiftly, this helps her "to be safe, and in more manageable terrain" (p. 102). She resorts to silence as a defense mechanism. This makes her life to be "organised and also puts her in tip-top" (p. 107). Her mind instructs her to work on her own logic. In order to get things done, the word "inveigle" (p. 108), comes to her rescue. It also injects her some sort of colour in her life. She begins to see herself as a "drifter, letting life happen to her" (p. 111).

Karuna has a chance to see life twists. When she sees this, a mature woman, she tries not to be shocked or perturbed. She does not like to live in the world of fantasy. She knows pretty well that life is not a movie, but it has to be treated in a real sense. Further, the appropriate reaction to real situations that she knows makes a life meaningful. She is such a pragmatic lady who is married to Bunty, a man of her choice. He is a management trainee in a multi-national company, she loves him "in her own way" (p. 55). During her initial years of her marriage, her husband talks to her about his plans and she, like a dutiful wife, listens to it and shows some enthusiasm. Unfortunately, "all this faded to nothing by the end of the first year of our marriage" (p. 69). In other words, she is struck in an increasingly meaningless marriage. She has a feeling that her marriage is a failure and also it becomes sour. She feels that she has married, "the wrong man for the wrong reasons at the wrong time" (p. 73). Though he is not a villain, he is just an average Indian husband, who is unexciting and uninspiring and untutored" (p. 73). 


\section{Crossing the Border: International Journal of Interdisciplinary Studies}

Karuna, as a typical Indian woman, "accepts him and accepts the marriage, sans passion, sans anything, because it suited me" (p. 73). In spite of this she does not like to excrete herself too much. Truly her husband is not a man looking for any stimulation, either intellectually or emotionally. As a result, she becomes "an exhausted generation of wives with no dreams left like our mother before us" (p. 73). Still, through her vibrato, she tries to live through them. She has stated that her husband is very low, and so she feels disgusted. She feels that neither the words nor the tone did anything "to allay the disgust I usually felt" (p. 76).

Karuna feels that "marriage is a skin allergy - an irritant all right, but not something that would totally incapacitate us" (p. 76). It is clear that her marriage is an utter failure. She and her husband have their own secrets in life. Lack of intimacy between them is absorbed in the following lines, "We had our own secret lives- and by that I do not mean clandestine affairs. But these were our private worlds, inaccessible to the men we had married. I could spend hours in this world, even when the husband was around talking to me" (p. 76). Marriage means laughter and conversation. It also involves "speaking the same language, thinking the same thoughts, enjoying the same things" (p. 76). Karuna feels that she is not only the victim of her husband's indifference, but also she comes across the same indifference on the part of the other husband's on their own wives. This creates a sort of uneasiness in her mind and in it she muses: "All the husbands of my friends more or less fell into this pattern. They were not evil men, but what they did to our lives went beyond evil, we were reduced to bring mariginal people. Everything that mattered to us was trivialized" (p. 77). Men, including Karuna's husband, consider the needs of women as secondary. In such a scenario, she has to fight with her husband. As a result, home has become a sort of battleground. So, she sees an aggression in him. Out of it, he shouts, "you are a spoilt woman - like other friends. You women want it both ways - your kick and your comfort" (p. 129). Though she is surprised, she tells him coolly that let's not fight and also with her maturing mind, she casually tells him, "I don't flirt at random like my other friends, I'm steady and grounded. It's the Taurean in me, that's surfacing these days. Treat this as a short-term mania that will wear it out and then we can go back to business as usual" (p. 229-30). Karuna expects from him, ten minutes of real conversation and further, Bunty's husband is too sensitive, funny. In her married life, she does not wish herself to be wife material and husband material. In fact, she wants to elude solitariness with solitary dreams. When she tries to talk to him endlessly about the things which have fascinated, her husband found her to be womanish and corny.

In addition, Karuna's husband has noticed crosscurrents in her, but he has pretended that he had not sensed it which proves to be a matter of worry to her. In such a scenario, she is tempted to ask her husband "about his attitudes" (p. 96). But she reaches a boiling point when her husband coolly says, "always I can relax in my own room" (p. 96), thinking that it is a matter of self-defense. This kind of attitude on the part of her husband makes her sense labefaction of her life. Out of it, she screams, "I had learnt to switch off. Switch off. Switch off. Switch off. Switch off. But I didn't want to anymore, I didn't want to deaden myself to life" (p. 96). But she is stifled by his lack of communication and solicitous liking to his mother, and makes her blurt out in the following manner: "I'm not concerned about your mother - she's not the person I Married - though I'm beginning to wonder. I'm talking about us - You and me. I think we are OK. We leave each other alone. You try not to get into yours. That's the best possible combination" (p. 230). Karuna's husband always keeps her out of his reach because of his suspicion. He thinks that Karuna has an affair with Krish which seem, when he boldly says, "Bastard! Drinks my boose and steals my wife" (p. 225). This kind of comment makes one to feel that he is a lowdown bastard. His uttering, "I have to deal with you Karuna" (p. 
225) shows his petty mindedness. It reaches further, when he says,

I admire your nerve. The way you are playing the high and mighty role, one would imagine the whole thing was my fault. Just get off your high horse and face life - you aren't in one of your books now, and I'm not the understanding husband they show in films. I have come here to thrash things out - and I mean business. I'll get myself a drink. If you want one, you can bloody well fix it yourself. 'I'm not your goddamned bartender'. (p. 225-226)

He also keeps her out of his reach. This creates a sort of revulsion in her and out of it, "she wants to kill him" (p. 103). Karuna does not like the "bada saab act" (p. 103), of her husband. Sometimes, this kind of act forces him to face snub from others. But, she sees his gauche and pretentious nature of him. This creates, in Karuna, impatience and of it, "she wants to yell" (p. 104) and also wishes to point out his attitude as tactless.

Karuna's husband, a man of machinator, comes out with lectures. She feels that these lectures, not only tend to be quaint, but also reduce her to zombie-like state. In her words, it has only a disastrous effect. Further, these lectures have created a sort of irritated eruption also. Her battered married life is absorbed by her in the following lines, "my books, even began, as before, to play a major part in our sex life" (p. 105). To her, her husband is only "a hardcover" (p. 106), in her life. Between them, they have only 'passionless, mechanical, encounter'. Even during this session, she says, "I'd be lying there thinking of the book of the moment and wondering what was going to happen next" (p. 106). The more her marriage deadened, the harder Karuna has tried to convince herself that she is happy enough as she is. Sometimes, there comes a voice in her which pushes her to ask a question, "why I didn't get the hell out of the marriage?" (p. 110). This sort of question in her turns out to be rebellious, in order to save her life from ill-mannered her husband. As a result, she wants to say goodbye to him. Her decision to forsake her husband is seen in her following lines, when she boldly says,

....Just get the hell out of my house and life. I don't ever want to see you again. I let you in this time - but never again. I'll call the cops if you try and invade my home in future. You are even more of a worm than I thought. You deserve Winnie - I hope she's got a wax doll of yours. I'll send her some extra pins to stick into it. Now that your frigging pipe and OUT!! (p. 327)

When her married life becomes a total disaster, she does not become fantod or a fussy person. She does not allow her life to be dominated by dullness. In fact, Karuna’s friends around her, like Charlie, Anjali, Ritu, Si, and Nisha, make her life dulcet and meaningful.

Charlie is always special to Karuna. She sees the world, "mainly through the prism of Charlie" (p. 14). She makes Karuna to be determined. As a result, Charlie herself put it, "I admired her lead and tried to follow her wherever I could" (p. 14). Charlie, in fact, is not only a source of inspiration, but also a person who helps her to see the outside world. Karuna says in this following line, "I remember sneaking into a theatre with her to see our first adult movie" (p. 15). Karuna always enjoys listening to Charlie's account of, "lipstick on your collar and high heeled pumps" (p. 15). Happily, she shares "all her adventures from experimenting with her Father's razor under the arms to stuffing her bra with cotton wool to look bigger" (p. 15). These are the occasions in which Charlie helps Karuna think about the limits of respectability. At the same time, Charlie helps Karuna to be a dare- devil. This nature of Charlie is absorbed by Karuna in the following lines, "She was also the first girl in school to own a pair of stretch pants. They were the absolute rage at the time, but girls from 'decent' families weren't allowed to wear them because they hugged the skin so. Charlie wore her fire- 


\section{Crossing the Border: International Journal of Interdisciplinary Studies}

engine-red pair to a school outing once and scandalized everybody" (p.16).

As a close and intimate friend, Charlie wants to create a sensation on Karuna and she has succeeded too. In fact, the whole family has detested Karuna. The more they disapprove of her friendship with Charlie, the more close Karuna becomes with her. The flashy way of Charlie, including Karuna, is always a sort of fascination to her. She loves the way Charlie has put herself to the matter pretending to gussy-up. Wherever Charlie goes out, Karuna tags with her always. Karuna is stunted to see Charlie, when she works with professional ease. In fact, Charlie helps Karuna to be "being self- consciousness" (p. 19) in order to be a valued person or an object. In a nutshell, Charlie is responsible for Karuna to become rebellious and also helps her to become a perfect con in modelling. Along with Charlie, another female character in the novel, who moulds the life of Karuna is Anjali. De portrays Anjali's life, though it is marked by suffering, as a woman of sensation. Anjali is very tall, statuesque. She is also sophisticated. She dresses beautiful and speaks divinely. When she was nineteen, she got married to Abbas known as Abe. At the time of her marriage, she served as an air hostess like other attractive girls of her generation. She wanted to be independent in her life and expresses in the following lines, "Basically, I wanted to get out of the closed, boring middle class environment of my family. I wasn't interested in studies. I wanted to be on my own, independent" (p. 5).

During the earlier days of her marriage, Abe had imagined that "she would be just another quick pick-up" (p. 5). But Anjali has proved that she is worldly wise and has managed to hook Abe. Though her marriage has become a total failure, she has "too far gone in her misery to camouflage the sordid of her life" (p. 25). In her married life, she has come across only the bad patch. But she is a type of a lady, who wishes to remain as a fun loving and confidant lady. She does not wish to be a mute admirer of things. Her subtle manipulation and courage is always a source inspiration to others, including Karuna. Whenever people listen to her, they resort to the peroration. Anjali always remains to be modest. She is ready to discuss her boredom of her life, openly with her friends. She does not like to face jinx. Her boldness is seen, when she is ready to face the challenge of the word by asking it in the form of the questions. She asks to come on Jinx-what's all this. She is in search of exotic life. In this regard, she is undeterred. She remains to be terrifically entertaining, in order to face crosscurrents of the life. Whenever the problems fall over her, she carefully plans to stumble over this. She is curiously looking forward to march her life when she is described as saying, "Though her marriage is an unhappy one and chafed at being under Abe's thumb" (p. 40), she does not pique by this.

Anjali does everything in order to come out of the brutal and boorish attitude of others, including her husband, Abe. Her husband sometimes remains her to be of Aristotle Onassis, a person known for crude arrogance. But she does not allow herself to be cowed down by the manly show off the male chauvinist, including Abe, her husband. She has always possessed a temperament, which is amazingly very good in nature. She always keeps herself under control, in order to save herself from the sidekick of others. She always bongs for the new side, which should be devoid of threat. She has a sense of competitiveness, and it makes her to be a star. The reactions of her sometimes have tended to be a sharp slap in the face. Her divorce is viewed as a kind of neglect, abuse and torture. Though it is considered to be a meaningless divorce, she tries to recover herself from vicarious existence. She always wants to be a striking woman. With all the years of experience behind her, she does not exist like a tiny doll. As a result, she has a chance to meet a government biggie in the income tax department. His love for her nails makes her and a government biggie comes close. In his fascination for 
it, he says, "may I touch your nails? I have never seen such beautiful nails before" (p. 85). But he has got temperament which has been marked by his possessiveness and this nauseating tendency frightens Anjali and boldly says goodbye to him in order to close another little chapter in her life. Anjali, after her nexus with an income tax official, tries to discover love with Pierrie, a French man. At first, she views him as a romantic man, who has brought a new life, a new world. Further, she thinks that he has managed to tap something within her. In other words, as she herself says, "he touches my soul" (p. 90) in order to make life meaningful. Unfortunately, he proves to be a man without a special mission when he says "His plain lazy and unambitious" (p. 92) that forces her to say good-bye to him. Being a woman who works for her own logic, she tries to renegotiate her life with Kumar, who is known as Kumar Bandari. She is not only drawn towards him, but also marries him because he does not look like pipsqueak.

Through her second marriage, Anjali works out for rules which do not hate her life anymore. She thinks that this marriage helps her to overcome teensy-weensie existence. The luxuries offered by Kumar to her, like canopy over her life more sweet and delicious. Everything, with Kumar, is gleaming and perfect. She has felt the heightened state with all her luxuries. This kind of existence, she candidly says: "I can feel my kundalini rising" (p. 171), bringing her peace and love. The way in which she decorates her own brings her to a state of trance. She has felt that she has attained a spiritual bliss. This gives her a lot of strength; nothing can get her down now. Kumar's encouraging words: "Go ahead, spend as much as you like" (p. 170), always act as a motivating expression. In fact, his religious inculcation helps her to know more about herself. In her ecstasy,

...the ecstasy I experience when I'm praying or listening to my bajans is far better than an orgasm. I'm into this totally, and sex has become irrelevant. In fact, I hate to use the sort of language we used to - you know - fuck-shuck and all that. I feel impure. I go and gargle immediately if these words come out by mistake. If I'm not near my own bathroom and it happens in someone else's house, I quickly take out my mint breathfreshener pump and do a fast whoosh whoosh. (p. 171)

To Anjali, being religious does not mean joining the ashram or giving up the life. She wants to enjoy both mundane and celestial experiences in her life. For this, it is apt to quote Anjalis words: "I still love my luxuries - nice saris, jewellery and all that. I'm just in a heightened state now, and I can feel my Kundalini rising and lifting me out of the mess I was in. What's wrong with that? What's wrong with peace and love?" (p. 171). It is clear that Anjali through coalescing spiritual and materialistic aspects of life wants to be ahead of her time. It helps her, to remain in with the trends. Even her husband feels proud of this and out of this, he utters, "you are my Kohinoor ... Nobody else matters" (p. 176). She is always stoic, storm, silence and deep as the Ganga.

To Karuna, Anjali is heaven-sent. Karuna observes Anjali in the following manner, "She has offered her the opportunity to be everything I ever wanted to be" (p. 9). When Karuna's hunger becomes great, it is taken care of by Anjali. She feels that she is lucky to have Anjali as her friend. She always considers Anjali as a very special person whenever Anjali extends her help to Karuna and cries in gratitude. Her friendship seems to be a sort of bliss by Anjali with her eloquence. Karuna's intimacy with Anjali helps her to get cues from her, which she considers not only a privilege but also a kind of thrill. She feels that Anjali is her friend and confidant.Karuna takes Anjali, as her heroine and she wishes, "to remain the wide-eyed fan, and mute admirer" (p. 26). Whenever Karuna sees Anjali, she is seen in her 'queenly self' (p. 26) by Karuna. Further, she is forced to wonder about their intimacy in 


\section{Crossing the Border: International Journal of Interdisciplinary Studies}

the form of meaningful questions. These questions have shocked herself, and out of this as she asks, "I said to myself. Why would she do that with me? I mean who was I? A nobody! She didn't have to entice me, surely. I hastily brushed away the thought. But even to this day, I often wonder" (p. 27).

Karuna, with the help of an aide Anjali, becomes a subtle manipulator and bravado. This helps her to be successful in modeling. Anjali's fulsome praise always helps her to achieve things in life. In fact, it helps Karuna to reach glories of the rich and famous. Whenever Karuna feels a sense of insecurity, she moves very close to Anjali aiming for her excessive love. In fact, Anjali takes her to exotic world in which she hears the shuffling movement, which helps her to investigate more on her life. Between Karuna and Anjali, there is something in which Karuna herself says, "unspoken compact between us" (p. 40). Whenever Karuna is suffering from low self-esteem, her relationship with Anjali becomes, a sort of "antiseptic 'relationship' and explain limply, "We have a lot to say to each other" (p. 40).

Anjalis attitude to women of the world has its impact on Karuna. In fact, it is observed that Karuna has become a permanent appendage to Anjali's sari hem. Anjali as a mentor shares her personal idiosyncrasies with Karuna and this helps her to get out of the watch strap. Karuna considers Anjali's advice as a refresher course and also it replenishes her energy. Anjali, as a true friend, shows her concern for Karuna. This creates amazement in Karuna's mind. It helps Karuna not only to be flashy, but also to be flamboyant. Whenever she meets Anjali, her animated advice helps her to be relaxed. As a result, her misery that is out of her sight helps her enjoy her life.

Anjali's amazing coolness is always helpful to Karuna. When Anjali tries to imitate this, Karuna feels a sort of control of herself and a kind of bang, which have its dangerous magic on her. In their relationship, Karuna views Anjali as her star. Anjali is an experienced woman trying to infuse courage on Karuna. This helps Karuna to resort to a strategy in which she says, "in time in my own way I worked out a formula that ensured peace if not bliss" (p. 78). Anjali as her inner voice and in it as she hears, "you look as if you are about to implode" (p. 78). The conversation between them tends to be a real conversation. It is a problem finding and also it helps Karuna to come out of her worry. The friendship between them has grown over the months at an unhurried pace. They like to speak to each other over the phone and like to meet from time to time. Their friendship remains as a formal relationship with welldefined rules. In fact, Karuna through her friendship with Anjali, tries to become studious and sincere.

Karuna's great love and respect help Anjali to feel worthy. In fact, Anjali helps her to unveil the world. As a result, she has sensed a change, which is suited of its softness. Anjali's friendship helps Karuna too much. It also helps her not to feel like a fool. The friendship guides her to be less self-obsessed and more giving. Through their friendship, Karun is too set in her ways. This reduces the major complication in her life and helps her to take a decision which is based on material consideration. Anjali's friendship with Karuna proves to be an exciting experience. This makes Karuna think that she is a woman with special missions in which selfishness does not matter to her. Along with Anjali, books, music and cooking not only come to her rescue, but also to overcome hiccup in her life. Karuna feels that Anjali's connection helps her to stave off her boredom. Also, her friendship helps Karuna to have her own devices and in it, she retreats more and more into her fantasy world.

Ritu, another prominent woman in De's Socialite Evenings, helps Karuna to know the positive aspects of life. Karuna observes about Ritu in the following way: "my soul comforts with Ritu" (p. 127). Also, Karuna feels that Ritu is a person "to be talked to and be with her" 
FROM MARGIN TO CENTRE

(p. 127). As a result, Karuna feels that Ritu has become a dominating force in her life. When Karuna behaves like a coy, Ritu helps Karuna about how to attract people of "all sorts, from little servant boys and to silver-haired industrialist" (p. 127). Ritu's advice helps Karuna about how to slobber man at her feet. Also, her advice helps her to come out of the difficulties of trampling men. Through her, Karuna learns about how to manage extremities of life. As a result, she becomes "spontaneous, vibrant, buoyant and fun" (p. 130). Ritu helps Karuna to get rid of anxiety-ridden and tense. Ritu also helps Karuna to take up destructive challenges around her and makes these challenges as an advantage because Ritu knows every nugget of her life. As a result, life has become a sort of enchantment. This helps Ritu to be more intimate with all. In fact, Karuna has learnt the art of overcoming embarrassment in life with the help of Ritu. Ritu proves to be scintillating to all because she always maintains cool composure, which helps her to get over the animosities in her life. The love between Ritu and Karuna is like a puppy love syndrome.

Karuna considers Ritu as her redeemer as she uses the word 'bravo' (p. 134), which is uttered by Ritu that acts as beacon to her. Karuna is always touched by Ritu's enthusiasm. There is no hostility between them. Karuna is genuinely glad for Ritu. With her, Ritu is always 'a quite something. Ritu's dulcet nature is always a source of inspiration to Karuna. Both of them go shopping expeditions in which they have the excitement and also feel denunciated. Both of them are ready to co-operate with each other and are willing to look after each other. Each time, they take a step in their life, which proves to be 'strategic spot light' without any wobble. Their friendship is similar to radiance without any sarcasm. It is, as if, "decked out in an elaborate Rajasthani ghagra in gold tissue" (p. 146). In their friendship, they never felt yucky i.e., any disgust, in it.

To sum up, the female protagonists of De like Karuna and Anjali are remarkable when measured against men, and even they are transformed from margin to centre. They are powerful and strong enough to revolt against every unfair treatment meted out to them. These women do not want to compromise. They long for a sense of achievement. With this quality, they want to climb the ladder to acquire the fame. They strive to discard the image as docile, weak and dependent women. These women characters have tremendous selfconfidence and enthusiasm to face every kind of challenge that hinders them from attaining their desired goal.

De reshapes her women characters as aggressive bolsters of the male ego and male hierarchy. As she herself reiterates: "The women in my books are not definitely doormats. They are not willing to be kicked around" (Singh, 2000, para. 4). She envisages that women must be treated as equal partners in every sphere of life. She is very firm that a day will come when women will have a very strong hold in every aspect of social, political and cultural affairs and their voice will be reckoned and heeded universally. David Davidhar hails De's novels as "serious attempts at discovering India through Indian eyes" (Vellani, 1991, p. 324). Thus, De expresses vociferously her feeling of detest against the patriarchal culture and strongly detests the marginalisation of women.

\section{REFERENCES}

De, S. (1989). Socialite evenings. New Delhi: Penguin Books.

Mahajan, P. (n.d.). Emergence of new woman: A new feministic approach in the select novels of Mahasweta Devi, Manju Kapoor, Rupa Bajwa and Shobha De. Retrieved from http:// shodh.inflibnet.ac.in:8080/jspui/bitstream/123456789/2111/1/synopsis.pdf/. 


\section{Crossing the Border: International Journal of Interdisciplinary Studies}

Pathak. R. S. (1997). Feminism in contemporary British and Indian fiction. Delhi: Sarup and Sons.

Singh, A. (2000, November 30). The trouble with men. Asiaweek. Retrived from http://edition. cnn.com/ASIANOW/asiaweek/97/0228/cs1.html/.

Vellani, S. (1991, August). Interview with David Davidar. Seminar, 384.

\section{ABOUT THE AUTHOR}

With 27 years of teaching experience, Dr. T.S. Ramesh is Associate Professor at the Department of English, National College (affiliated with Bharathidasan University), Trichirappalli, Tamil Nadu, India. He has supervised M.Phil and Ph.D. students' theses and published several research articles in different journals. His area of interest and expertise includes Indian Writing in English. Email: <drtsramesh@gmail.com>.

R. Vanitha is Assistant Professor at the Department of English, National College (affliated with Bharathidasan University), Trichirappalli, Tamil Nadu, India. She has 11 years of teaching experience and her area of interest includes Indian Writing in English. 